\title{
Inhibition of the T cell oxygen sensing machinery promotes anti-tumor efficacy
}

\author{
David Clever ${ }^{*}$, Rahul Roychoudhuri, Nicholas P Restifo \\ From 30th Annual Meeting and Associated Programs of the Society for Immunotherapy of Cancer (SITC \\ 2015) \\ National Harbor, MD, USA. 4-8 November 2015
}

Mechanisms of immune tolerance can also be co-opted by tumors to subvert anti-tumor effector $\mathrm{T}$ cell responses. The lung represents a unique anatomic tissue of pronounced immune tolerance where $T$ lymphocytes do not mount effector responses under steady state conditions despite continual exposure to innocuous foreign antigens. We hypothesized that a cell intrinsic mechanism by which $\mathrm{T}$ lymphocyte behavior is modulated to promote local immune suppression within the lungs can be inhibited to promote anti-tumor $\mathrm{T}$ effector responses. Here, we demonstrate that the family of prolyl-hydroxylase (Phd) proteins promote $\mathrm{T}$ cell tolerance in the lung and limit anti-tumor $\mathrm{T}$ cell responses throughout the body. Prolylhydroxylase isoforms 1, 2, and 3 functioned redundantly as oxygen sensors in $\mathrm{T}$ lymphocytes and enabled environmental oxygen to limit effector differentiation in vitro and in vivo. Mice with a T-cell specific deletion of all three Phd proteins (Phd-tKO) developed spontaneous Th1mediated immunopathology in the lungs. Phd-tKO CD4 ${ }^{+}$ $T$ lymphocytes activated under normoxic conditions or wild-type $\mathrm{T}$ cells activated under oxygen-deprivation conditions exhibited reduced specification into $\mathrm{T}$ regulatory cells (Treg) and instead defaulted to a Th1 program as revealed by whole transcriptome RNA-sequence profiling and induction of Tbet and IFNg protein expression. This predisposition to effector cell specification in the absence of Phd protein expression or under oxygen deprivation was dependent on the functional expression of the hypoxia inducible proteins HIF1a and HIF2a. Importantly, genetic or pharmacologic inhibition of the Phd proteins in tumor antigen-specific $\mathrm{CD} 4^{+} \mathrm{T}$ cells promoted anti-tumor efficacy in murine models of adoptive cell transfer immunotherapy as indicated by increased tumor clearance and improved overall survival of tumor-bearing mice. These

\footnotetext{
Surgery Branch, National Institutes of Health, National Cancer Institute,
} Bethesda, MD, USA

(c) 2015 Clever et al. This is an Open Access article distributed under the terms of the Creative Commons Attribution License (http:// creativecommons.org/licenses/by/4.0), which permits unrestricted use, distribution, and reproduction in any medium, provided the original work is properly cited. The Creative Commons Public Domain Dedication waiver (http://creativecommons.org/publicdomain/ zero/1.0/) applies to the data made available in this article, unless otherwise stated. findings establish the oxygen sensing Phd proteins as a $\mathrm{T}$ cell intrinsic regulatory node in immune homeostasis that may be targeted genetically or pharmacologically to promote anti-tumor immune responses.

Published: 4 November 2015

doi:10.1186/2051-1426-3-S2-O1

Cite this article as: Clever et al:: Inhibition of the T cell oxygen sensing machinery promotes anti-tumor efficacy. Journal for ImmunoTherapy of Cancer 2015 3(Suppl 2):01.

Submit your next manuscript to BioMed Central and take full advantage of:

- Convenient online submission

- Thorough peer review

- No space constraints or color figure charges

- Immediate publication on acceptance

- Inclusion in PubMed, CAS, Scopus and Google Scholar

- Research which is freely available for redistribution 